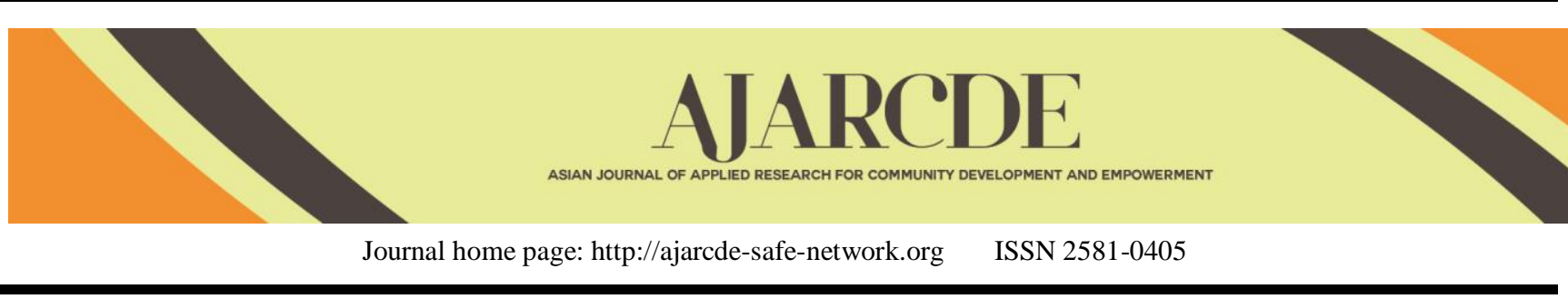

\title{
Analysis of Cocoa Supply Chain Risk in Kare Village, Madiun District with Method Analytic Network Process
}

\author{
Risqi Firdaus Setiawan, Pawana Nur Indah and Endang Yektiningsih \\ Department of Agriculture, Faculty of Agriculture, University of Pembangunan National Veteran East Java, Surabaya city, Indonesia \\ Corresponding author: pawana_ni@upnjatim.ac.id
}

\section{ARTICLE INFO}

Article History::

Received: 23 May 2020

Final Revision: 19 July 2020

Accepted: 21 July 2020

Online Publication: 9 August 2020

\section{KEYWORDS}

Risk Management, Cocoa, Supply Chain, ANP, FMEA

\section{CORRESPONDING AUTHOR}

*E-mail: pawana_ni@upnjatim.ac.id

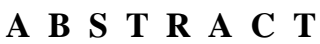

Cocoa is one of the plantation commodities whose role is quite important for the national economy of Indonesia. However, the cocoa industry faces several problems including the various risks involved in the cocoa supply chain. The aim of this study were: 1) Identifying risks in the cocoa supply chain 2) Analyzing the members of the supply chain with the highest risk 3) Evaluating and mitigating cocoa supply chain risks effectively and efficiently. An integrated analytic network process (ANP) and weighted failure mode effect analysis (WFMEA) method will be used to determine and analyze the highest risk in the cocoa supply chain. The results of the priority of the members of the value chain in the cocoa supply chain risk management are SMEs $(0.43801)$, with the risk having the highest priority is production risk $(0.29262)$ as well as alternative strategic priorities namely by increasing income (0.28754). The results of risk control are mainly focused on efforts to increase the income of cocoa farmers by utilizing cocoa processing byproducts such as cocoa bean pulp and cocoa pod husks. The cocoa bean pulp can be processed into nata products and cocoa juice, while the cocoa pod skin can be used as fertilizer.

\section{INTRODUCTION}

\subsection{Research Background}

Cocoa is one of the five mainstay Indonesian commodities in the plantation sector [1]. The cocoa commodity is the third largest contributor of all national plantation product exports after oil palm and coffee. In 2015, foreign exchange contributed by the commodity reached USD 1.30 billion [2]. The number of cocoa agro-industries has increased with the government policy regarding the development of the cocoa processing industry through the downstream program. The increasing number of the cocoa industry has caused the demand for cocoa to also increase.

The national productivity value of cocoa plantations in Madiun is still low, at an average of $2,833 \mathrm{~kg} /$ year, even though the potential productivity of plants can reach more than $3,000 \mathrm{~kg}$ / year. There is a decrease in productivity in Madiun Regency. This is due to the relatively high level of risk in each member of the supply chain. in the agricultural sub-sector known as the term farm to the table [3].
Technically, supply chain management in agricultural products is more complex compared to non-agriculture, due to the perisbale, seasonal, bulky, scattered production locations with diverse quality qualifications. [4]. These special characteristics influence the process of agricultural production. This imbalance will pose risks for each member of the cocoa supply chain. The presence of risk in agriculture has long been seen as having a significant influence on farmers' production and investment decisions, therefore a good risk management concept is needed. [5] components in risk management in agricultural commodities, namely: identifying and measuring sources of risk, evaluating risk management alternatives, and adjusting risk control to each of the actors along the supply chain. To support the optimization of efforts to increase sales at the company [6].

Supply chain is a material, information and money flow whose subject matter covers the management of resources owned by an institution or individual, integrated to achieve the objectives [7]. The challenges of the global market and the added value of cocoa have the consequence of the need to increase competitiveness in the supply chain of the cocoa industry, hence the need for efforts to identify risks, assess risks, and mitigate risks. After the priority of supply chain risks is known, a supply chain risk management is needed in the form of risk management 
in the cocoa supply chain in Madiun Regency. Related to the risks in supply chain management, risk management plays an important role in ensuring that the supply chain system is not disrupted [8]. The method used to identify risks in the cocoa supply chain for each member of the supply chain actors by using the Analytical Network Process (ANP). in order to get the risk with the highest priority based on the interrelationship between sub-criteria and criteria [9]. so that risk priorities and alternative risk control options can be determined to make better decisions. The results obtained from ANP in the form of identification of the most influential risk weights in the cocoa supply chain. The risk analysis and evaluation stage is generally carried out using the Failure Mode Effect Analysis (FMEA) method [9], but in my opinion [10], the method only assesses risk without considering alternative relations of interest with mitigation plans. So to calculate the weight of each risk and its relationship with risk mitigation in each member of the supply chain actors, the integration between ANP and FMEA methods is used. This stage uses a new approach namely Weighted Failure Mode Effect Analysis (WFMEA) which is a technique to recognize and evaluate the failure of a product or process introduced by [11]. The weight obtained from the results of risk identification through ANP is used as a multiplier weight to produce a Weighted Risk Priority Number (WRPN) assessment, which is the multiplication of the risk weight with the severity of the failure that occurs, the level of frequency of failure that occurs, and the level the ability to detect failure [8]. The results of WRPN show the seriousness of the potential failure, the higher the value of WRPN, the risk has a top priority risk control [12]. With good risk management, it is expected that risks in the cocoa supply chain can be managed so that it can produce a robust supply chain and increase the competitive advantage of cocoa.

\subsection{Literature Review}

\subsubsection{Supply Chain Risk Management}

Supply chain risk management is a coordinated activity among all supply chain actors [13]. Risk arises from the existence of an uncertainty. Uncertainty about events that occur internal and external to the company results in the emergence of a kind of threat that can result in both operational and financial losses to the company. Supply chain risk basically refers to the likelihood and effect of mismatches between supply and demand. Furthermore, the consequences of risk can be associated with specific supply chain outputs such as cost or quality [14]. Supply chain risk can be defined as damage caused by events in the supply chain or its environment that has a negative effect on the supply chain business processes of more than one company. [15]

\subsubsection{Supply Chain Management}

Supply chain or supply chain is a series of collections of companies that are interdependent sequentially and cooperate in controlling, managing, and improving the flow of goods, money, and information from the supplier side upstream to the end user side. A supply chain can be defined as a network consisting of several companies (including suppliers, manufacturers, distributors and retailers) that collaborate and engage directly or indirectly in meeting consumer demand [17]. Supply chain management examines the efficiency and effectiveness of the flow of goods, information and money flows that occur continuously by involving related parties. In practice, SCM can integrate producers, suppliers, retailers and sellers efficiently [18].

\subsubsection{Cacao}

Theobroma cacao is the biological name given to the cacao tree by Linnaeus in 1753. The natural place of the genus Theobroma is in a part of tropical forest with a lot of rainfall, high humidity, and shade. Under these conditions, Theobroma cacao rarely bears fruit and produces only a few seeds. Cocoa plants consist of 2 (two) types which are distinguished based on the color of the seeds, the white color belongs to the Criollo group, while the seeds of the purple plant belong to the Forastero group. Cocoa beans are needed in various industries because of their unique characteristics, namely: (1) cocoa beans contain quite high fat $(55 \%)$, where the fat has a unique characteristic that is frozen at room temperature but melts at body temperature, (2) the solid part of the cocoa beans contains components of flavor and coloring which are highly needed in the food industry.

\subsection{Research Objective}

The objectives of this study are (1) Identifying risks in the cocoa supply chain (2) Analyzing the members of the supply chain with the highest risk (3) Evaluating and mitigating cocoa supply chain risks effectively and efficiently.

\section{MATERIALS AND METHODS}

\subsection{Data Types and Sources}

The data used are primary and secondary data. Secondary data was obtained from documents, literature, scientific journals, reports of previous relevant studies as well as from various sources such as the Central Bureau of Statistics, Ministry of Agriculture, Ministry of Trade, Ministry of Industry, research centers, associations, company data that were the object of study, and parties relevant parties. Whereas primary data was obtained through several methods, namely field observations, interviews and expert opinions. For data on the value of severity, occurrence and correlation of each risk impact and risk causes obtained from distributing questionnaires to related parties [19].

\subsection{Sampling Method}

Sampling is based on non-probability sampling where the collection of information and knowledge from experts uses a purposive sampling method to determine the experts involved in research. The considerations used to determine experts are the suitability of expert education, expert experience and track record expertise.

\subsection{Analytical methods}

The reality shows that the cocoa commodity industry in Indonesia is not well developed [2] caused by several risk factors that hamper, then we need a risk management of the cocoa supply chain that is identifying risk factors with the ANP method. Then the risk analysis and evaluation is carried out using the WFMEA method. Furthermore, risk control can be carried out in order to increase competitive advantage and create competitiveness in cocoa commodities. 
Data analysis at the risk identification stage uses ANP. ANP is an analytical tool that is able to represent the level of importance of various parties [20] by considering the dependency relationship between criteria and sub-criteria, pairwise comparisons are needed to determine priorities [21]. The ANP method is used to calculate the weight of supply chain performance by noting the level of dependency between groups or clusters. Data processing in this study was carried out with the help of Superdecision 2.2.6 software.

The risk analysis and evaluation stage is carried out using the WFMEA method introduced by Ref. [11]. This method is a development of the FMEA model. FMEA is determined based on the opinion of Cocoa agro-industry supply chain experts [22]. In general, this method aims to obtain a more accurate assessment after aggregating the relationship between risk factors for which weighted priorities have been calculated. According to [10], FMEA assessments are generally carried out using a risk priority number (RPN). The essence of this technique is the aspect that influences the potential (risk) failure of supply chain system elements, which is stated in severity $(\mathrm{S})$, occurrence $(\mathrm{O})$ and detection (D) [3]. The WFMEA method uses a weighted assessment to obtain more accurate and continuous results from the previous stage of risk assessment [23]. The weight of each risk can be calculated using the WRPN calculation formula with the equation formula.

WRPNn $=$ Si $\mathrm{x}$ Oi $\mathrm{x}$ Di $\mathrm{x} f(\mathrm{Wi})=\mathrm{RPNn} \times f(\mathrm{Wi})$

Information:

Si : Severity

Oi : Occurrence

Di : Detection

$f(\mathrm{Wi})$ : Weight

Failure modes that have a higher RPN are assumed to be more important and are given a higher priority than a lower RPN. Risk Evaluation is comparing the level of risk that has been calculated at the risk analysis stage with the standard criteria used [22]. The variable output value, WRPN, is used to represent priorities for corrective actions on a scale of 1-250, which are categorized into five interval classes described in Table 1.

Table 1 Risk Categories by WRPN

\begin{tabular}{lll}
\hline Output Value & Risk Category & Risk Control \\
\hline $1-50$ & Very Low & Receive \\
$50-100$ & Low & Receive \\
$100-150$ & Intermediate & Avoid \\
$150-200$ & High & Mitigation \\
$200-250$ & Very High & Mitigation \\
\hline
\end{tabular}

Source : [24]

\section{RESULT AND DISCUSSION}

\subsection{Cocoa Supply Chain Risk Identification}

Product supply chain is an activity that starts from raw materials to after-sales handling. This supply chain includes activities that occur due to relationships with producers, suppliers, and customer relations [25]. This activity is a separate activity but very much dependent on one another. The cocoa commodity supply chain in Kare Village, Madiun can be simply illustrated in Figure 1.

Based on the results of literature studies and brainstorming, as well as in-depth interviews with several experts, the ANP framework was obtained to identify the risk of cocoa commodity supply chains. The ANP method divides the indicators used in the cluster [26]. The ANP structure can be shown in Figure 2. This structure consists of three clusters: 1) Cluster Problems in the form of cocoa commodity supply chain risk management problems. 2) Risk Cluster is an alternative risk factor identified from the results of in-depth interviews with experts and literature study results, 3) Actor Cluster means actors who play a role in the supply chain of cocoa commodities

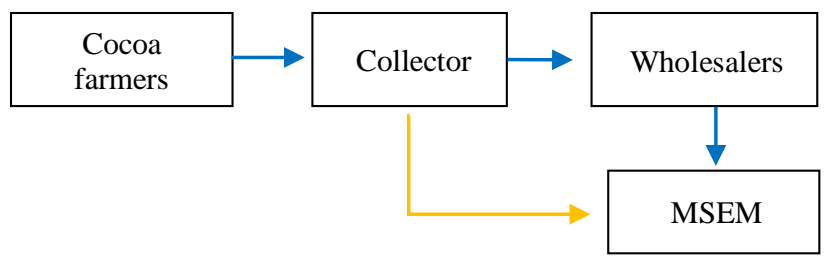

Fig.1. Cocoa Supply Chain in the village of Kare, Madiun

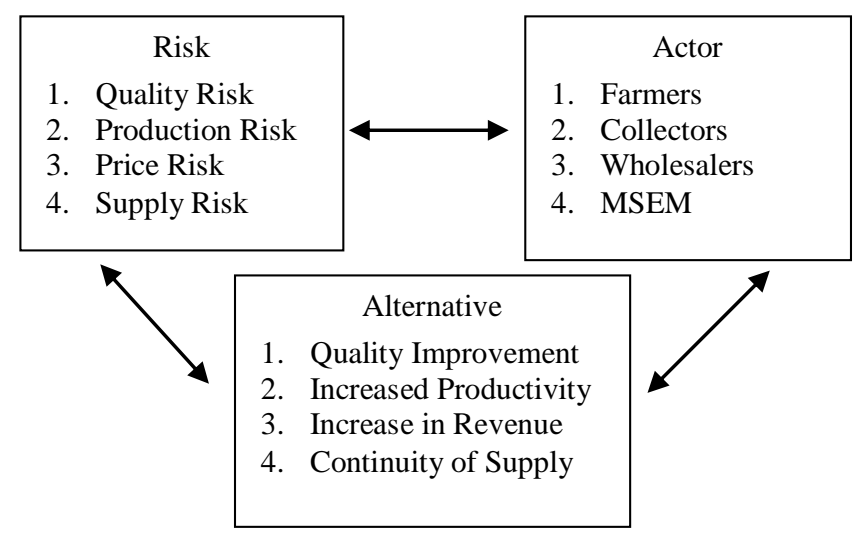

Fig. 2. ANP general framework

\subsubsection{Priority for Actor Clusters}

Selection of actor clusters in the cocoa supply chain is based on actors involved in the scope of research, namely farmers, collectors, wholesalers and industry [27]. The determination of actor cluster priorities can be seen in Figure 3

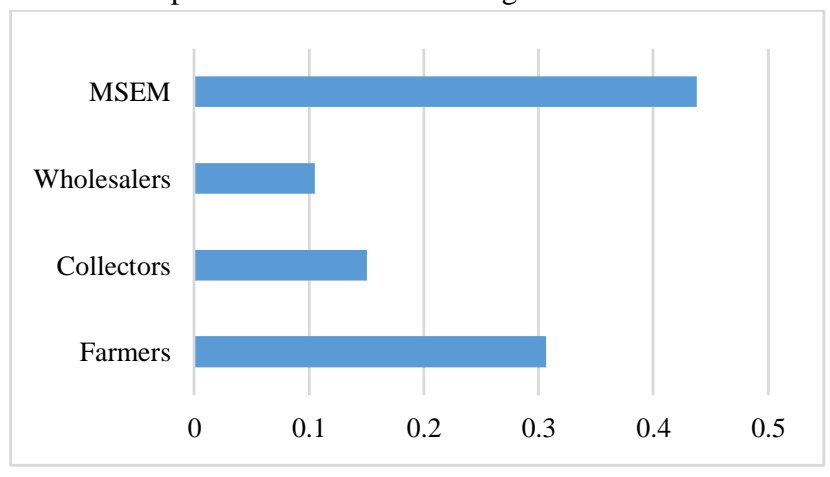

Fig. 3. Priority cluster of actors

Based on Figure 3, the clusters considered to be the most influential on improving the performance and value added of the cocoa supply chain are industries with priority values of 0.43801 . 
The Indonesian cocoa industry has an important role in the acquisition of foreign exchange and employment. The cocoa industry in Indonesia has broad links both upstream and downstream. The industry has a high dependency on cocoa quality related to consumer demand. So that the industry has a high commitment to produce processed cocoa of the highest quality [23]. The quality of processed cocoa produced will also determine the selling price, the better the quality of processed cocoa, the higher the selling price which will certainly increase added value. The development of the cocoa industry is not only by increasing added value, but it can also be done by increasing the use of processed cocoa products for domestic production.

\subsubsection{Risk Cluster Priority}

Supply chain risk factors that occur in the cocoa supply chain have been identified through literature studies, in-depth discussions with supply chain actors and prior research conducted by [23]. Based on this, there are four cocoa supply chain risks that are the focus of the risk cluster, namely quality risk, production risk, price risk and supply risk. The results of the cocoa supply chain risk cluster priority analysis can be seen in Figure 4.

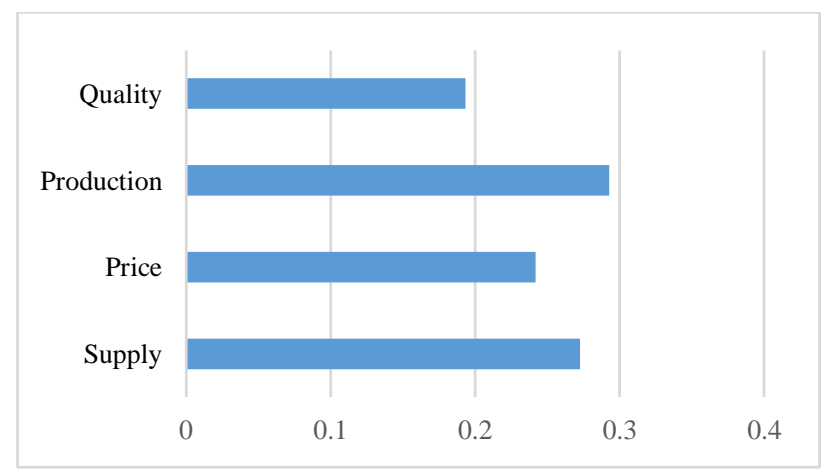

Fig. 4. Priority risk clusters

The results of the priority analysis show that production risk is considered the most influential in the cocoa supply chain with a priority value of 0.29262 Production risks in the cocoa supply chain include limited production capacity, low quality raw materials, and the use of simple production technology. Cocoa production is closely related to the availability of cocoa as an industrial raw material. Cocoa production has been declining lately, making cocoa supply to the domestic industry insufficient. Therefore, Indonesia is still importing cocoa to meet domestic cocoa needs. Production risks occur in both the plantation and processing sectors. In the plantation sector, production risks that occur are pests and diseases that often attack cocoa plants and can affect the quantity and quality of the production produced [28]. The low production of cocoa is also caused by many conditions of care and maintenance of the garden. Therefore, this production risk must get more attention for supply chain actors who are closely related to production activities such as farmers and the cocoa industry.

\subsubsection{Alternative Strategic Cluster Priorities}

Strategic alternative clusters contain several alternative strategies formulated based on problems and risks that exist in the cocoa supply chain. The results in the alternative cluster strategy are shown in Figure 5. The results of the alternative cluster priorities show that the element of increasing income has the highest priority with a priority value of 0.28754 . The income of members of the supply chain in the upstream sector is generally still low, especially farmers. The quality of Indonesian cocoa, especially those produced by the people, is still valued the lowest on the international market because it is considered to be poor. The level of benefits obtained by cocoa supply chain actors is still very volatile and not optimal, so there are still opportunities to increase the income of cocoa supply chain members by increasing added value. Increasing added value to farmers can be done by utilizing cocoa processing byproducts such as cocoa bean pulp and cocoa pod husks. The cocoa bean pulp can be processed into nata products and cocoa juice, while the cocoa pod skin can be used as fertilizer. Cocoa bean pulp contains between 12-15\% sugar compounds so it is good enough for nata making media. Making nata can be done on a home industry scale because the production process and equipment are simple.

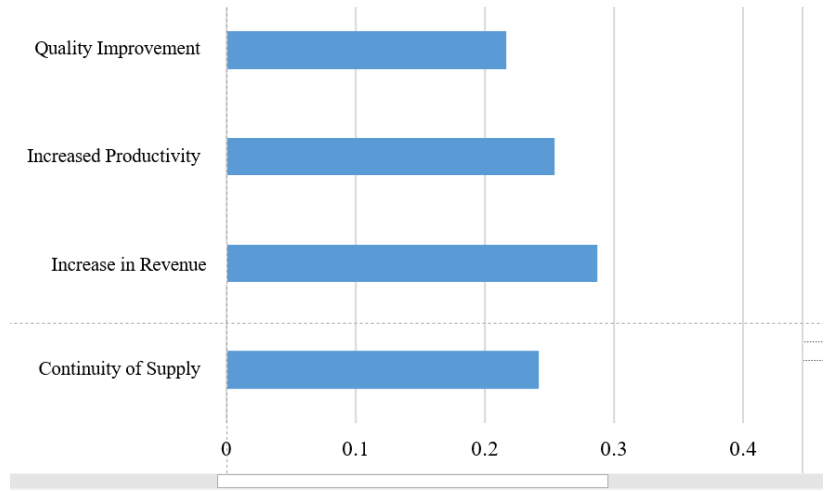

Fig. 5. Priority alternative cluster strategies

\subsection{Analysis and Evaluation of Cocoa Supply Chain Risks}

Risk analysis is carried out to distinguish acceptable minor risks from major risks, and to provide data that will help the risk evaluation and control stage. Risk evaluation is a comparison between the level of risk obtained from the results of calculations with the standard criteria used [29]. The experts assess the risk of each supply chain that is identified in terms of severity, occurance, and detection and each expert assesses based on the experience he has [27]. The risk assessment stage is assisted by the WFMEA method. The three components of severity, occurrence, and detection are multiplied by the risk weight, resulting in a Weighted Risk Priority Numbers (WRPN) value. The results of the risk assessment from the opinion of experts can be seen in Table 2 .

To get a more accurate and integrated analysis of problems and supply chain members, a WRPN calculation using weight (W) is carried out, which is obtained from the priority results of risk identification. The results of the analysis of expert risk factor assessments and risk variables with the ANP method are listed in Table 3. There is a slight difference between the results of calculations before and after weighted, namely the difference in the order of the first risk, namely supply risk, second quality risk. While the production and price risk factors do not change and rank in the same order. The results of the analysis using WRPN calculations are more reliable because they take into account the more detailed weighting of various risk factors that occur along the cocoa supply chain. 
Risk Evaluation is comparing the level of risk that has been calculated at the risk analysis stage with the standard criteria used. Based on the risk category, it can be concluded that the very low risk category is price risk (WRPN 169.4). The low risk category is production risk (WRPN 261.94). The medium risk category is quality risk (WRPN 308.63) the high risk category is supply risk (WRPN 316.41) so risk control is needed in the form of mitigation.

\subsection{Highest Risk Management of Cocoa Supply Chain}

Risk control in the form of risk mitigation and contingency plans involves the development of risk response plans to control risk [30]. Determination of appropriate actions to be taken in supply chain risk management refers to the results of identification and evaluation of supply chain risks that have been carried out previously [27]. Some of the risk control measures described in this section are mitigation processes that can be carried out based on the greatest risk priority, namely supply risk. The company actor has a risk at the stage of providing supplies for retailer delivery requests [31].

Table 2. FMEA expert assessment results

\begin{tabular}{|c|c|c|c|c|c|c|}
\hline No & Risk Factors & Risk Variable & $\begin{array}{l}\text { Severity } \\
(1-10)\end{array}$ & $\begin{array}{c}\text { Occurance } \\
(1-10)\end{array}$ & $\begin{array}{c}\text { Detection } \\
(1-10)\end{array}$ & RPN \\
\hline \multirow[t]{5}{*}{1} & \multirow[t]{5}{*}{ Quality } & Season and weather are erratic & 7.5 & 7 & 6.5 & 341.25 \\
\hline & & The low quality of raw material supply & 7 & 6.5 & 5 & 227.5 \\
\hline & & Low cultivation technique knowledge & 7 & 7 & 7 & 343 \\
\hline & & Insufficient storage facilities & 6.5 & 6 & 7 & 273 \\
\hline & & Pests and Diseases & 8.5 & 7.5 & 6.5 & 414.37 \\
\hline \multirow[t]{3}{*}{2} & \multirow[t]{3}{*}{ Production } & Limited production capacity & 6 & 6.5 & 7 & 273 \\
\hline & & The quality of raw materials is low & 7 & 7 & 7.5 & 367.5 \\
\hline & & Use of simple production technology & 6 & 6.5 & 6.5 & 253.5 \\
\hline \multirow[t]{3}{*}{3} & \multirow[t]{3}{*}{ Price } & Inflation & 4 & 5.5 & 7 & 154 \\
\hline & & Price fluctuations & 7.5 & 7 & 6 & 315 \\
\hline & & Rupiah exchange rate with bank interest & 7 & 5.5 & 6 & 231 \\
\hline \multirow[t]{4}{*}{4} & \multirow[t]{4}{*}{ Supply } & Diversity of supply quality & 7.5 & 7 & 7 & 367.5 \\
\hline & & Supplier loyalty & 6 & 6.5 & 5.5 & 214.5 \\
\hline & & Uncertain supply availability & 6.5 & 6 & 6 & 234 \\
\hline & & Quality certification risk & 7 & 7 & 7 & 343 \\
\hline
\end{tabular}

Source: Processed Data, 2020

Table 3. RPN and WRPN Result

\begin{tabular}{|l|c|c|c|c|c|c|}
\hline \multicolumn{1}{|c|}{ Risk } & ANP $(\mathrm{W})$ & Ranking & RPN & Ranking & WRPN & Ranking \\
\hline Quality & 0.193 & 4 & 1599.1 & 1 & 308.63 & 2 \\
\hline Production & 0.293 & 1 & 894 & 3 & 261.94 & 3 \\
\hline Price & 0.242 & 3 & 700 & 4 & 169.4 & 4 \\
\hline Supply & 0.273 & 2 & 1159 & 2 & 316.41 & 1 \\
\hline
\end{tabular}

Source: Processed Data, 2020

To overcome the low income of farmers, it can be done by utilizing cocoa processing byproducts such as cocoa bean pulp and cocoa pod husks. The cocoa bean pulp can be processed into nata products and cocoa juice, while the cocoa pod skin can be used as fertilizer. So that it can increase the income of farmers through byproducts from cocoa.

\section{CONCLUSION}

The conclusion of this study is that the cocoa supply chain consists of farmers, collectors, wholesalers, and industry. Risks identified in the cocoa supply chain are quality, production, price, and supply risks. ANP results, priority results from members of the cocoa commodity supply chain actors in supply chain risk

18 Setiawan et al. management are SMEs (0.43801), with the risk having the highest priority is production risk (0.29262) as well as alternative strategic priorities namely by increasing income (0.28754). ANP weighting and FMEA integration show results that consider alternative interest relationships with mitigation plans for each member of the supply chain. Based on WFMEA results, supply risk remains in the first place with WRPN 316.41. The results of risk control are mainly focused on efforts to increase the income of cocoa farmers by utilizing cocoa processing byproducts such as cocoa bean pulp and cocoa pod husks. The cocoa bean pulp can be processed into nata products and cocoa juice, while the cocoa pod skin can be used as fertilizer. 


\section{REFERENCE}

[1] G. Taib and P. D. Hari, "Analisis Rantai Pasok Dan Pemasaran Biji Kopi Di Sumatera Barat," J. Teknol. Pertan. Andalas, vol. 23, no. 1, p. 111, 2019, doi: 10.25077/jtpa.23.1.111-116.2019.

[2] Direktorat Jenderal Perkebunan Indonesia, "Statistik Perkebunan Indonesia," Direktorat Jenderal Perkeb. Indones., vol. 1, no. December 2014, p. 96, 2018.

[3] R. Jaya et al., "Analisis Dan Mitigasi Risiko Rantai Pasok Minyak Pala Kabupaten Aceh Selatan Menggunakan Fmeca," J. Teknol. Ind. Pertan., vol. 29, no. 1, pp. 79-87, Apr. 2019, doi: 10.24961/j.tek.ind.pert.2019.29.1.79.

[4] C. Ganeshkumar, M. Pachayappan, and G. Madanmohan, "Agri-food Supply Chain Management: Literature Review," Intell. Inf. Manag., vol. 09, no. 02, pp. 68-96, 2017, doi: 10.4236/iim.2017.92004.

[5] G. Bond and B. Wonder, "Risk Attitudes Amongst Australian Farmers: a Comment," Aust. J. Agric. Econ., vol. 25, no. 1, pp. 73-76, 1981, doi: 10.1111/j.14678489.1981.tb00385.x.

[6] H. T. Irawan, I. Pamungkas, and Muzakir, "Analisis risiko rantai pasok komoditas cengkeh di kecamatan salang kabupaten simeulue," Optimalisasi, vol. 5, no. 2 , pp. 72-81, 2019.

[7] A. Corominas, Research into the area of supply chain. 2017.

[8] M. Ulfah, M. Syamsul, Sukardi, and S. Raharja, "Analisis dan Perbaikan Manajemen Resiko Rantai Pasok Gula Rafinansi Dengan Pendekatan House of Risk," J. Teknol. Ind. Pertan., vol. 26, no. 1, pp. 87-103, 2016.

[9] N. Ashari, "Analisis Nilai Tambah dan Risiko Rantai Pasok Keripik Usus Ayam ( Studi Kasus : UKM Hikmah , Klaten )," pp. 1-15, 2019.

[10] J. K. Chen, "Utility Priority Number Evaluation for FMEA,” J. Fail. Anal. Prev., vol. 7, no. 5, pp. 321-328, 2007, doi: 10.1007/s11668-007-9060-2.

[11] N.-C. Xiao, H.-Z. Huang, Y. Li, L. He, and T. Jin, "Multiple failure modes analysis and weighted risk priority number evaluation in FMEA," Eng. Fail. Anal., vol. 18, pp. 1162-1170, Jun. 2011, doi: 10.1016/j.engfailanal.2011.02.004.

[12] N. Badariah et al., "Analisa Supply Chain Risk Management Berdasarkan Metode Failure Mode and Effects Analysis ( Fmea )," J. Tek. Ind., pp. 110-118, 2013.

[13] I. A. Risqiyah and I. Santoso, "Risiko Rantai Pasok Agroindustri Salak Menggunakan Fuzzy FMEA," $J$. Manaj. dan Agribisnis, vol. 14, no. 1, pp. 1-11, 2017, doi: 10.17358/jma.14.1.1.

[14] E. Fitridia, E. Siata, and Edison, "Analisis Nilai Tambah dan Risiko Usaha Pada Agroindustri Serundeng Ubi Jalar di Kecamatan Siulak Kabupaten Kerinci," Agribisnis, no. Cv, pp. 2-11, 2017.

[15] R. U. Fahadha, T. Nuryati, and S. Sutarto, "Evaluasi Risiko Rantai Pasok pada Komoditas Bawang Merah di Lampung," Opsi, vol. 12, no. 2, p. 108, 2019, doi: 10.31315/opsi.v12i2.3162

[16] V. Der Vorst and J. G.A.J., "Performance measurement in agri-food supply-chain networks," in Quantifying the Agri-Food supply Chain, 2006.

[17] A. M. Ari Andriyas Puji, "Analisis dan Perbaikan Manajemen Risiko Rantai Pasok Safirah Collection dengan Pendekatan HOR," Semin. Nas. IENACO, vol. 53, no. 9, pp. 449-456, 2019, doi: 10.1017/CBO9781107415324.004.

[18] N. R. Timisela and E. D. Leatemia, "Supply Chain Management Of Agro Industry Of Cassava," J. Aplied
Manag., vol. 15, no. 1, pp. 135-145, 2017.

[19] R. Ambarwati, "Analisis Nilai Tambah dan Risiko Rantai Pasok Keripik Bayam ( Studi Kasus: UKM Khasanah )," pp. 1-16, 2019.

[20] T. L. Saaty, Theory and Applications of the Analytic Network Process: Decision Making with Benefits, Opportunities, Costs, and Risks, RWS Publications, Pittsburgh. 2005.

[21] S. Susanawati, J. Jamhari, M. Masyhuri, and D. Hadi Darwanto, "Identifikasi Risiko Rantai Pasok Bawang Merah di Kabupaten Nganjuk," Agrar. J. Agribus. Rural Dev. Res., vol. 3, no. 1, pp. 15-22, 2017, doi: 10.18196/agr.3140.

[22] S. Nasution, Y. Arkeman, K. Soewardi, and T. Djatna, "Identifikasi Dan Evaluasi Risiko Menggunakan Fuzzy Fmea Pada Rantai Pasok Agroindustri Udang," J. Ris. Ind., vol. 8, no. 2, pp. 135-146, 2014.

[23] H. Aini, M. Syamsun, and A. Setiawan, "Risiko Rantai Pasok Kakao Di Indonesia Dengan Metode Analytic Network Process Dan Failure Mode Effect Analysis Terintegrasi," J. Manaj. Agribisnis, vol. 11, no. 3, pp. 209-219, 2015, doi: 10.17358/jma.11.3.209-219.

[24] J. Jenkins, J. Ahern, D. Cock, S. Shutler, R. Smalley, and S. Hooper, A Guide to Supply Chain Risk Management. 2010.

[25] A. I. Rosyidi, H. Suliantoro, and A. Susanty, "Pengukuran Risiko Rantai Pasok Beras Menggunakan Fuzzy Failure Mode Effect Analysis (Studi Kasus : UD.Sami Hasil Demak)," Ind. Eng. Online J., vol. 5, no. $1,2016$.

[26] H. Saputra, N. Nazir, R. Yenrina, J. T. Ryacudu, W. Hui, and J. Agung, "Identifikasi tingkat risiko dan strategi pengendalian risiko pada rantai pasok gambir," Semin. Nas. Mesin dan Ind., vol. 12, pp. 149-157, 2018.

[27] E. A. Winanto and I. Santoso, "Integrasi Metode Fuzzy Fmea Dan Ahp Dalam Analisis Dan Mitigasi Risiko Rantai Pasok Bawang Merah," Teknol. dan Ind. Has. Pertan., vol. 22, no. 1, pp. 21-32, 2017.

[28] M. Cahya and E. Wulandari, "Risiko Rantai Pasok Paprika Pada Anggota Kelompok Tani Dewa Family, Kabupaten Bandung Barat," J. Pemikir. Masy. Ilm. Berwawasan Agribisnis, vol. 5, no. 2, pp. 252-275, 2017, doi: 10.1017/CBO9781107415324.004.

[29] et al., "Manajemen Risiko Rantai Pasok Agroindustri Gula Merah Tebu di Kabupaten Agam, Provinsi Sumatera Barat," Ind. J. Teknol. dan Manaj. Agroindustri, vol. 8, no. 2, pp. 133-144, 2019, doi: 10.21776/ub.industria.2019.008.02.6.

[30] R. Tummala and T. Schoenherr, "Assessing and managing risks using the Supply Chain Risk Management Process (SCRMP)," Supply Chain Manag., vol. 16, no. 6, pp. 474-483, 2011, doi: $10.1108 / 13598541111171165$.

[31] M. A. Kamal, T. Djatna, and Sukardi, "Pengelolaan Risiko Rantai Pasok Sayuran Organik (Studi Kasus: Pt. X, Cisarua, Kabupaten Bogor, Jawa Barat," Teknol. Ind. Has. Pertan., vol. 24, no. 1, pp. 15-30, 2019. 